\title{
PENGARUH PSIKOLOGIS KONSUMEN, PROMOSI DAN GRUP REFERENSI TERHADAP KEPUTUSAN PEMBELIAN PADA STASIUN PENGISIAN BAHAN BAKAR UMUM (SPBU) KOTA PALU
}

\author{
${ }^{1}$ Faigah A Badjamal, ${ }^{2}$ Firza Umar Salim, ${ }^{3}$ Marjun, \\ ${ }^{4}$ Abd Azis, ${ }^{5}$ Ani Khuryatul Abadiyah \\ (Dosen Fakultas Ekonomi Universitas Alkhairaat)
}

\begin{abstract}
ABSTRAK
Tujuan dari penelitian ini adalah (1). Untuk mengetahui dan menganalisis Psikologis, promosi dan grup referensi serempak berpengaruh terhadap keputusan pembelian pada SPBU Kota Palu. (2). Untuk mengetahui dan menganalisis Psikologis konsumen berpengaruh terhadap keputusan pembelian pada SPBU Kota Palu. (3). Untuk mengetahui dan menganalisis Promosi berpengaruh terhadap keputusan pembelian pada SPBU Kota Palu. (4). Untuk mengetahui dan menganalisis Grup referensi berpengaruh terhadap keputusan pembelian pada SPBU Kota Palu. Adapun hasil penelitian yang di dapatkan dilapangan bahwa nilai R-Square menunjukkan seberapa besar pengaruh variabel independen dalam penelitian ini secara keseluruhan. Nilai R-square dalam penelitian ini adalah sebesar 0,613 nilai tersebut menunjukan variabel independen Psikologi $\left(\mathrm{X}_{1}\right)$, Promosi $\left(\mathrm{X}_{2}\right)$, Grup referensi $\left(\mathrm{X}_{3}\right)$, terhadap keputusan pembelian $(\mathrm{Y})$ mempunyai pengaruh sebesar 61,3\% terhadap keputusan pembelian dan FDR. Sedangkan 39,7\% dipengaruhi oleh faktor variabel lain yang tidak dimasukan dalam penelitian ini. Psikologis, promosi dan grup referensi serempak berpengaruh terhadap keputusan pembelian pada SPBU Kota Palu. Psikologis konsumen berpengaruh terhadap keputusan pembelian pada SPBU Kota Palu. Promosi berpengaruh terhadap keputusan pembelian pada SPBU Kota Palu. Grup referensi berpengaruh terhadap keputusan pembelian pada SPBU Kota Palu.
\end{abstract}

\section{Kata Kunci: Psikologi, Promosi, grup referensi dam keputusan pembelian}

\section{LATAR BELAKANG}

Dewasa ini persaingan bisnis di Indonesia semakin ketat dan semakin tajam baik dalam perusahaan industri manufaktur maupun perusahaan jasa. Untuk menghadapi hal ini maka setiap perusahaan harus terus menerus meningkatkan kualitas produk atau jasanya. Agar dapat bersaing dan dapat memiliki produk maupun jasa yang bermutu perusahaan harus mempunyai strategi-strategi khusus untuk memenangkan persaingan pasar.

Pemasaran merupakan salah satu ujung tombak bagi sebuah perusahaan dan yang biasanya menjadi tolak ukurnya keberhasilan usaha. Dalam persaingan perusahaan diwakili oleh merk yang berhubungan erat dalam mempengaruhi citra konsumen. Dinamika persaingan antara merk dalam benak konsumen, mempunyai kedudukan yang unik jika dibandingkan dengan merk lain. Pengukuran kualitas sutau produk, diperlukan kajian terhadap dimensi atau atribut tertentu yang melekat pada produk tersebut. Jika perusahaan dalam merancang penawaran dan citra dapat menempati suatu proses kompetitif yang berarti perusahaan yang bersangkutan dapat menentukan posisinya.

Sebagai lokomotif perekonomian bangsa pertamina bangsa pertamina merupakan perusahaan milik Negara yang bergerak di bidang energi meliputi minyak, gas serta energi baru dan terbarukan.

Kegiatan usaha di bidang penyelenggaraan usaha energi, yaitu minyak dan gas bumi, energi baru dan terbarukan, serta kegiatan lain yang terkait atau menunjang kegiatan usaha di bidang energi, yaitu minyak dan gas bumi, energi baru dan terbarukan tersebut serta pengembangan optimalisasi sumber daya yang dimiliki perusahaan.

Pertamina memasarkan SPBU retail unuk sektor tranportasi, rumah tangga dan nelayan melalui SPBU (Stasiun Pengisian SPBU untuk Umum)yang tersebar di seluruh Indonesia. SPBU Di Kota Palu dan sekitarnya dipasok dari terminal 
SPBU Donggala. Terminal SPBU Donggala menyediakan beberapa jenis bahan bakar:

Bahan bakar bermesin bensin

\section{Pertamax Racing}

Merupakan bahan bakar kendaraan yang diakui federasi balap internasional, menjadikan mesin lebih responsive, lebih stabil, dan memiliki daya tahan yang tinggi, serta bersahabat dengan lingkungan. Pertamax Rancing memiliki oktan minimal 100 yang khusus diperuntukkan bagi kendaraan balap dan kendaraan yang memiliki kompresi mesin lebih tinggi dari 13:1.

2. Pertamax Turbo

Merupakan bahan bakar untuk kendaraan bermesin bensin yang dikembangkan bersama antara Pertamina dan Lamborghini yang dirancang untuk memenuhi persyaratan mesin bertehnologi tinggi. Pertamax Turbo pertama kali di luncurkan di Belgia sebagai bahan bakar resmi pada Lamborghini Supertrofeo European Series pada 39 juli 2016. Pertamax Turbo dikembangkan dengan formula yang disebut Ignition Boots Formula (IBF) dengan angka oktan 98, dan kadar sulfur rendah sehingga tidak merusak kualitas udara di sekitar kita. Petamax Turbo menuju standard Euro IV. Kelebihan dan manfaat Pertamax Turbo terhadap mesin :

- Meningkatkan drivability kendaraan sehingga lincah bermanuver

- Akselerasi mesin menjadi lebih bagus karena torsi yang dihasilkan lebih tinggi

- Meningkatkan kecepatan maksimal (top speed) kendaraan

- Peningkatan tenaga mesin kendaraan

- Menyempurnakan pembakaran bahan bakar pada mesin

\section{Pertamax}

Merupakan bahan bakar bensin dengan angka oktan minimal 92 berstandar internasional. Pertamax sangat direkomendasikan untuk digunakan pada kendaraan yang memiliki kompresi rasio 10:1 hingga 11:1 atau kendaraan berbahan bakar bensin yang menggunakan tehnolgi setara dengan Electronic Fuel Injection (EFI). Dengan ecovase technology, Pertamax mampu membersihkan bagian dalam mesin (detergency), Pertamax juga dilengkapi dengan pelindung anti karat pada dinding tangki kendaraan, saluran bahan bakar dan ruang bakar mesin (corrotion inhibitor), serta mampu menjaga kemurnian bahan bakar dari campuran air hingga pembakaran menjadi lebih sempurna (demulsifier).

4. Pertalite

Merupakan bahan bakar gasoline yang memiliki angka oktan 90 serta berwarna hijau terang dan jernih ini sangat tepat digunakan oleh kendaraan dengan kompresi 9:1 hingga 10:1. Bahan bakar pertalite memiliki angka oktan yang lebih tinggi dari pada bahan bakar Premium 88 sehingga lebih tepat digunakan untuk kendaraan bermesin bensin yang saat ini beredar di Indonesia. Dengan tambahan additive, Pertalite mampu menempuh jarak yang lebih jauh dengan tetap memastikan kualitas dan haega terjangkau.

5. Premium

Merupakan bahan bakar mesin bensin dengan angka oktan minimal 88 diproduksi sesuai dengan Keputusan Direktorat Jendral Minyak dan Gas Bumi Np.3674/K24/DJM/2006 tanggal 17 Maret 2006 tentang Spesifikasi Bahan Bakear Minyak Jenis Bensin 88. Premium dapat digunakan pada kendaraan bermotor bensin dengan resiko kompresi rendah (dibawah 9:1).

Bahan bakar bermesin diesel

1. Pertamina Dex

Merupakan bahan bakar diesel terbaik yang mampu menjadikan kinerja mesin lebih optimal, tangguh, dan bertenaga. Pertamina Dex dilengkapi dengan lubricity dan anti foaming og gas. Sangat disarankan untuk kendaraan diesel, terutama mesin diesel modern berteknologi Common Rail System yang memang membutuhkan bahan bakar prima dan berkualitas tinggi. Dengan kandungan sulfurnya yang rendah (kurang dari $300 \mathrm{ppm}$ ) dan dengan angka cetane 53 serta telah memenuhi standar Euro 3, menjadikanya sejajar dengan bahan bakar diesel premium kelas dunia.

2. Dexlite

Merupakan varian bahan bakar diesel terbaru dari pertamina yang diluncurkan pada tanggal 15 April 2016. Dexlite, member terbaru dari Dex Series, memiliki angka cetane minimal 51 dan mengandung Sulfur maksimal 1200 ppm. Dexlite sangat cocok diesel anda namun dengan harga yabg terjangkau. 
3. Solar

Merupakan bahan bakar diesel dengan angka cenate 48 sesuai untuk kendaraan bermesin diesel dengan teknologi lama dengan kandungan sulfur $250 \mathrm{ppm}$. Umumnya kendaraan ini dipakai untuk angkutan umum seperti bus dalam kota. Untuk kendaraan pribadi berbahan bakar diesel dapat menggunakan produk Dexlite dan Pertamina Dex.

Masing-masing merek tersebut untuk membuat produknya lebih unggul dibandingkan dengan merek lain. Sehingga kegiatan pemasaran yang baik dan tepatlah yang memegang peranan penting dalam menunjang kelangsungan usaha dan perkembangan suatu perusahaan. Tentunya pihak produsen harus mampu merebut hati konsumen akan hasil produksi yang dijual dan berupaya untuk memuaskan kebutuhan konsumennya.

Menurut (Badjamal, 2019) Dalam melakukan pembelian, konsumen dipengaruhi oleh beberapa faktor diantarannya faktor budaya, social, pribadi dan psikologis, maka penelitian ini bertujuan untuk mengetahui faktor psikologis yang menentukan keputusan konsumen dalam melakukan pembelian SPBU yang sedang marak di kota-kota besar salah satunya kota Palu. Oleh karena itu penulis berusaha menganalisis faktor-faktor yang memengaruhi keptusan pembelian produk SPBU terutama mengenai faktor psikologis yang mencakup faktor mitivasi, persepsi, pengetahuan serta keyakinan (sikap), dimana faktor tersebut menjadi faktor yang dianggap dominan dalam keputusan pembelian. Faktor psikologi merupakan salah satu faktor yang mempengaruhi konsumen dalam membeli SPBU dikarenakan setiap konsumen mempunyai psikologis yang berbeda-beda sehingga dalam menentukan pilihan produk yang akan dibelinya, sesuai konsumen akan tergantung pada mitivasi, persepsi serta pengetahuan dan keyakinan yang dimilikinya sehingga bermuara pada keputusan konsumen tersebut dalam menentukan jenis produk apa yang akan dimilikinya tersebut.

Menurut (Akhmad \& Latoki, 2021) Faktor psikologis sebagai pengaruh lingkungan dimana ia tinggal dan hidup pada waktu sekarang tanpa mengabaikan pengaruh dimasa lampau atau antisipasinya pada waktu yang akan datang. Dalam hal ini faktor psikologis konsumen dalam melakukan keputusan pembelian SPBU dapat dilihat dari berbagai faktor yang terdiri dari motivasi, persepsi, pengetahuan, keyakinan dan sikap.

Menurut (Umar A, 2019) Sebagai salah satu komponen dari bauran pemasaran, peran promosi dalam mempengaruhi keputusan pembelian tentu tidak bisa dianggap remeh. Dalam penelitian ini promosi diartikan sebagai suatu komunikasi persuasif yang dilakukan produsen untuk menarik konsumen membeli produknya.

Kelompok acuan (refence group) adalah seorang individu atau sekelompok orang yang secara nyata mempengaruhi perilaku seseorang. Kelompok acuan di gunakan oleh seseorang sebagai dasar untuk perbandingan ada sebuah referensi dalam membentuk respon afektif, kognitif, dan perilaku. Kelompok acuan akan memberikan standard an nilai yang akan mempengaruhi perilaku seseorang.

Berdasarkan fenomena tersebut di atas maka penelitian mencoba mengkaji secara empiric ke dalam sebuah penelitian dengan judul "Pengaruh Psikologis Konsumen, Promosi dan Grup Referensi Terhadap Keputusan Pemebelian SPBU di Kota Palu".

Berdasarkan latar belakang penelitian di atas, maka dapat di rumuskan pemasalah penelitian ini sebagai berikut:

1. Apakah psikologis, promosi dan grup referensi serempak berpengaruh terhadap keputusan pembelian SPBU di Kota Palu?
2. Apakah psikologis konsumen berpengaruh terhadap keputusan pembelian SPBU Di Kota Palu

3. Apakah promosi berpengaruh terhadap keputusan pembelian SPBU di Kota Palu

4. Apakah grup referensi berpengaruh terhadap keputusan pembelian SPBU di Kota Palu

\section{METODE PENELITIAN}

Jenis penelitian ini merupakan penelitian deskriptif kasual. Tipe penelitian deskriptif dilakukan untuk membuat deskriptsi atau gambaran secara sistematis dan akurat mengenai fakta-fakta yang diteliti. Menurut Gay (dalam Umar, 2005:21) bahwa metode riset deskriptif 
bertujuan untuk menjawab pertanyaan menyangkut sesuatu pada waktu berlangsungnya riset. Tujuan penelitian kausal adalah penelitian untuk menguji hubungan kausalitas antara variabel yang hipotesakan.

Penelitian kausal mencoba menghasilkan informasi ilmiah melalui pengujian hipotesis, yang akan menggambarkan hubungan antara dua atau lebih variabel untuk mengetahui apakah suatu variabel berasosiasi atau tidak dengan variabel lainnya. Kausalitas merupakan sebagai suatu langkah untuk mengevaluasi hubungan antar variabel yang diteliti dalam bentuk pengujian hipotesis. Penelitian ini dilakukan untuk menganalisis pengaruh faktor psikologis konsumen dalam melakukan keputusan pembelian SPBU di Kota Palu.

Sampel adalah sebagian dari populasi. Teknik pengambilan sampel yang digunakan dalam penelitian ini adalah teknik accidental sampling. Untuk mengefisiensikan waktu dan biaya, maka dengan ini peneliti menggunakan batas minimum dari teori yang dikemukakan Hair di atas, yaitu 5 (lima) dikali dengan jumlah indicator penelitian. Dengan demikian dapat dihasilkan jumlah sampel sebagai berikut: 16 indikator x $5=80$ sampel. Jadi, jumlah sampel yang digunakan dalam penelitian ini sebanyak 80 orang sampel.

Untuk menguji kebenaran hipotesis penelitian, penulis menggunakan alat statistic parametric, yaitu Regresi Linear Berganda dengan persamaan formulasinya adalah sebagai berikut (Sugiono, 2004:211):

$$
Y=b_{0}+b_{1} X_{1}+b_{2} X_{2}+b_{3} X_{3}+b_{4} X_{4}+\ldots \ldots . .+b_{n} X_{n}+e
$$

Dimana :

$$
\begin{array}{ll}
\mathrm{Y} & =\text { variabel tak bebas } \\
\mathrm{b}_{0} & =\text { intersep } \\
\mathrm{b}_{1} \mathrm{~b}_{\mathrm{n}} & =\text { besaran koefisien }
\end{array}
$$

regresi

$$
\begin{array}{ll}
\mathrm{X}_{1} \mathrm{X}_{\mathrm{n}} & =\text { variabel bebas } \\
\mathrm{e} & =\text { variabel gangguan }
\end{array}
$$

jika variabel penelitian dimasukkan pada persamaan di atas,maka diperoleh persamaan regresi untuk masing-masing variabel penelitian sebagai berikut:

$$
\begin{aligned}
& \mathbf{Y}=\mathrm{b}_{0}+\mathrm{b}_{1} \mathrm{X}_{1}+\mathrm{b}_{2} \mathrm{X}_{2}+\mathrm{b}_{3} \mathrm{X}_{3}+\mathrm{b}_{4} \mathrm{X}_{4}+\mathrm{e} \\
& \text { Dimana : } \\
& \mathrm{Y}=\text { Keputusan Pembelian } \\
& \mathrm{X}_{1} \quad=\text { Psikologi }
\end{aligned}
$$

$$
\begin{array}{ll}
\mathrm{X}_{2} & =\text { promosi } \\
\mathrm{X}_{3} & =\text { grup referensi } \\
\mathrm{b}_{0} & =\text { Konstanta (intercept) } \\
\mathrm{e} & =\text { error (tingkat kesalahan) }
\end{array}
$$

Untuk menguji kebenaran hipotesis pertama (pengaruh kedua variabel bebas secara serempak terhadap variabel tidak bebas) digunakan pengujian statistic uji-F, dengan formulasi sebagai berikut:

$$
\mathrm{Uji}-\mathrm{F}=\frac{\mathrm{R}^{2} /(\mathrm{K}-1)}{\left(\mathrm{I}-\mathrm{R}^{2}\right) /(\mathrm{n}-\mathrm{k})}
$$

Dimana :

$$
\begin{aligned}
& \mathrm{F}=\text { Diperoleh dari tabel distribusi } \mathrm{F} \\
& \mathrm{R}_{2}=\text { Koefisien determinasi ganda } \\
& \mathrm{k}=\text { Jumlah variabel independen } \\
& \mathrm{n}=\text { Jumlah sampel }
\end{aligned}
$$

Adapun kaidah pengambilan keputusan untuk pengujian hipotesis sebagai berikut:

a. Jika $\mathrm{p}<\mathrm{a}(0,05)$ Artinya, terdapat yang signifikan secara serempak psikologi, promosi dan grup referensi terhadap keputusan pembelian SPBU di Kota Palu.

b. Jika $\mathrm{p}>\mathrm{a}$ (0.05) Artinya, tidak terdapat pengaruh yang signifikan secara serempak pskologi, promosi dan grup referensi terhadap keputusan pembelian SPBU di Kotaa Palu.

Adapun kaidah pengambilan keputusan untuk pengujian hipotesis sebagai berikut:

a. Jika $\mathrm{p}<\mathrm{a}(0,05)$ Artinya, terdapat pengaruh yang signifikan secara serempak psikologi, promosi dan grup referensi terhadap keputusan pembelian SPBU di Kota Palu.

b. Jika $\mathrm{p}>\mathrm{a}(0,05)$ Artinya, tidak terdapat pengaruh yang signifikan secara serenpak psikologi, promosi dan grup referensi terhadap keputusan pembelian SPBU di Kota Palu.

Untuk menguji kebenaran hipotesis (dua sampai dengan empat) pengaruh dari masingmasing faktor bebas secara parsial terhadap keputusan pembelian ban motor merk FDR di Kota Palu, digunakan uji-t, dengan formulasi dari Rangkuti (2000:33) sebagai berikut :

$$
\mathrm{tbi}=\frac{\mathrm{bi}}{\mathrm{Sbi}}
$$

Dimana : 


$$
\begin{aligned}
& \mathrm{t}=\text { Diperoleh dari daftar tabel } \mathrm{t} \\
& \mathrm{b}=\text { Parameter estimasi } \\
& \mathrm{Sb}=\text { Standar Error }
\end{aligned}
$$

Kaidah pengambilan keputusannya adalah sebagai berikut :

a. Jika $\mathrm{p}<\mathrm{a}(0,05)$ Artinya, terdapat pengaruh yang signifikan secara parsial psikologi, promosi dan grup referensi terhadap keputusan pembelian SPBU di Kota Palu.

b. Jika $\mathrm{p}>\mathrm{a}(0.05)$ Artinya, tidak terdapat pengaruh yang signifikan secara parsial psikologi, promosi dan grup refernsi terhadap keputusan pembelian SPBU di Kota Palu.

Dalam pengolahan data menggunakan uji regresi linear berganda, dilakukan beberapa tahapan untuk mencari hubungan antara variabelvariabel independen dan variabel dependen, melalui pengaruh psikolog $\left(\mathrm{X}_{1}\right)$, promosi $\left(\mathrm{X}_{2}\right)$, grup referensi $\left(\mathrm{X}_{3}\right)$, terhadap kepuasan pembelian (Y). hasil regresi dalam penelitian dapat dilihat pada tabel 4.16 di bawah ini.

Tabel 4.16

Hasil Pengujian Regresi Linear Berganda

\begin{tabular}{|l|c|c|c|}
\hline \multirow{2}{*}{ Model } & $\begin{array}{c}\text { Standardized } \\
\text { Coefficients }\end{array}$ & \multirow{2}{*}{$\mathrm{t}$} & \multirow{2}{*}{ Sig. } \\
\cline { 2 - 2 } & Beta & & \\
\hline (Constant) & .229 & .451 & .653 \\
\hline Psikologi $\left(\mathrm{X}_{1}\right)$ & .187 & 2.105 & .039 \\
\hline Promosi $\left(\mathrm{X}_{2}\right)$ & .201 & 2.437 & .017 \\
\hline Grup referensi $\left(\mathrm{X}_{3}\right)$ & .699 & 9.198 & .000 \\
\hline R Square & $=0,613$ & \\
Fhitung & $=29.709$ & \\
Adjusted R Square & $=0,592$ & \\
a & $=0,05$ & \\
Multiple R & $=0,783$ & \\
\hline
\end{tabular}

Sumber ;Hasil uji regresi, 2020

Dari hasil regresi yang tertera pada Tabel 4.16 di atas, dapat diketahui behwa persamaan regresinya adalah :

$$
Y=0,229+0,201+0,699
$$

Berdasarkan persamaan regresi yang diperoleh maka dinyatakan bahwa variabel independen psikologi $\left(\mathrm{X}_{1}\right)$, promosi $\left(\mathrm{X}_{2}\right)$, grup referensi $\left(\mathrm{X}_{3}\right)$, untuk nilai koefisien dapat diuraikan sebagai berikut :

a. Koefisien psikologi 0,187, nilai ini menunjukan bahwa terdapat hubungan positif antara variabel psikologi dengan keputusan pembelian yang mengindikasikan apabila terdapat perubahan terhadap variabel psikologi maka keputusan pembelian akan berubah pula secara positif.

b. Koefisien promosi 0,201, nilai menunjukkan terdapat hubungan positif antara variabel promosi dengan keputusan pembelian, yang mengindikasikan apabila terdapat perubahan pada promosi maka keputusan pembelian akan beruba pula secara positif.

c. Koefisien grup referensi 0,699, nilai ini menunjukkan terdapat hubungan positif antara variabel grup referensi dengan keputusan pembelian, yang mengindifikasikan apabila terdapat perubahan pada variabel grup referensi maka keputusan pembelian akan berunah pula secara positif.

d. Dari hasil perhitungan yang ditunjukkan pada tabel 4.16 nilai Multiple $\mathrm{R}$ memperoleh nilai sebesar 0,783 , yang artinya terdapat hubungan positif keseluruhan variabel psikologi $\left(\mathrm{X}_{1}\right)$, promosi $\left(\mathrm{X}_{2}\right)$, grup referensi $\left(\mathrm{X}_{3}\right)$, terhadap keputusan pembelian (Y).

\section{Pembahasan Hasil Penelitian Pengaruh Psikologi $\left(\mathrm{X}_{1}\right)$ terhadap Keputusan Pembelian}

Faktor psikologis sebagai pengaruh lingkungan dimana ia tinggal dan hidup pada waktu sekarang tanpa mengabaikan pengaruh dimasa lampau atau antisipasinya pada waktu yang akan datang. Berdasarkan hasil perhitungan regresi diperoleh nilai koefisien variabel psikologi sebesar 0,187. Hal ini menunjukkan terdapat hubungan positif antara variabel psikologi dengan keputusan pembelian. Sedangkan nilai thitung diperoleh 2.105 pada tingkat signifikan 0,039.

Dari keseluruhan nilai diatas dapat disimpulkan variabel psikologi merupakan salah satu faktor yang mempengaruhi keputusan pembelian SPBU di Kota Palu. Menurut Kotler (Bernard, 2009:31), melalui bertindak dan belajar orang mendapatkan keyakinan dan sikap. Keduanya kemudian mempengaruhi perilaku pembelian mereka. Keyakinan menggambarkan 
mengenai seseorang yang mempercayai sesuatu. Seseorang percaya tentang perubahan keputusan pembelian produk atau jasa. Sikap sama pentingnya dengan keyakinan, dimana sikap adalah evaluasi seseorang terhadap suka atau tidak suka, perasaan dan tindakan mereka terhadap sesuatu.

Hal tersebut sesuai dengan fenomena dilapangan dimana salah satu keputusan pembelian karna motivasi, persepsi, dan keyakinan, atau dengan kata lain konsumen memilih menggunakan SPBU karena persepsi melihat bentuk dari SPBU dan ketahanan SPBU yang dimiliki.

\section{Pengaruh Promosi terhadap Keputusan Pembelian (Y)}

Berdasarkan hasil perhitungan regresi diperoleh nilai koefisien variabel promosi sebesar 0,201 . Hal ini menunjukan terdapat hubungan yang positif antara variabel promosi dengan keputusan pembelian sedangkan nilai $t$ hitung sebesar 2,437 pada tingkat signifikan 0,017. Sehingga dapat disimpulkan terdapat pengaruh yang signifikan antara variabel promosi dengan keputusan pembelian.

Promosi berpengaruh signifikan dikarenakan masyarakat pengguna SPBU yang dijadikan sampel dalam penelitian begitu memperhatikan publisitas beredar dipasaran tentang SPBU, mereka cukup melihat dan menilai sendiri bagaimana kualitas dari SPBU itu sendiri.

Promosi juga salah satu bentuk khusus komunikasi untuk memenuhi fungsi pemasaran. Promosi akan membawa dan mengarahkan konsumen membeli produk-produk SPBU yang telah dirancang oleh produsen. Promosiyang baik akan mampu menarik perhatian konsumen agar tertarik untuk membeli produk, serta mampu memberikan respon pembeli yang kuat. Pada umumnya sebelum konsumen melakukan keputusan pembelian konsumen biasanya mengumpulkan informasi-informasi melalui sumber-sumber informasi seperti browsing, televisi, dan sumber informasi lainnya. Informasi tersebut digunakan untuk menentukan pilihan akhir atau keputusan beli konsumen.

\section{Pengaruh grup referensi $\left(\mathbf{X}_{3}\right)$ terhadap} Keputusan Pembelian (Y)

Grup referensi adalah setiap orang atau kelompok yang dianggap sebagai dasar perbandingan (atau rujukan) bagi seseorang dalam membentuk nilai-nilai dan sikap umum atau khusus, atau pedoman khusus bagi perilaku. Nilai koefien dari variabel pengetahuan sebesar 0,699 yang artinya tedapat hubungan positif antara grup referensi ditingkatkan maka keputusan pembelian akan meningkat pula. Sementara nilai $\mathrm{t}$ hitung sebesar 9,198 dengan tingkat signifikan 0,000, yang artinya terdapat pengaruh yang signifikan antara variabel grup referensi terhadap keputusan pembelian SPBU di Kota Palu.

Variabel grup referensi dikatakan memiliki pengaruh yang signifikan dikarenakan responden dalam melakukan pembelian cenderung pengaruh nilai ekspresif yaitu banyak melihat dari teman-teman yang lain, belajar dari pengalaman yang dijadikan pengetahuan mereka terhadap kualitas SPBU tersebut. Faktor-faktor inilah yang menyebabkan variabel grup referensi beerpengaruh signifikan terhadap keputusan konsumen.

Penelitian ini diperkuat oleh teori dari Kotler, (1998) menyatakan bahwa kebanyakan proses komunikasi antar manusia adalah dari mulut ke mulut. Setiap orang setiap hari berbicara dengan yang lainnya, saling tukar pikiran, saling tukar informasi, saling berkomentar dan peroses komunikasi yang lainnya. Mungkin sebenarnya pengetahuan konsumen atas berbagai macam merek produk lebih banyak disebabkan adanya komunikasi dari mulut ke mulut. Hal itu terjadi karena informasi dari teman akan lebih dapat dipercaya dibandingkan dengan informasi yang diperoleh dari iklan.

Variabel yang Berpengaruh Paling Dominan

Untuk menentukan variabel bebas yang paling dominan dalam mempengaruhi nilai dependen variabel dalam suatu model regresi linear, maka gunakanlah koefisien Beta, koefisien tersebut Standardized coefficient. Dari hasil penelitian dapat diketahui bahwa variabel yang paling dominan adalah variabel grup referensi $\left(\mathrm{X}_{3}\right)$ yang ditunjukan dengan koefisien beta $(\beta)$ terbesar yaitu sebesar 0,699. Hal ini sesuai dengan hipotesis yang menyatakan behwa terdapat variabel berpengaruh paling dominan.

\section{KESIMPULAN DAN SARAN Kesimpulan}

Berdasarkan hasil penelitian yang mengangkat judul tentang Pengaruh Psikologis, Promosi dan Grup referensi terhadap Keputusan Pembelian SPBU DI Kota Palu dapat disimpulkan: 
1. Psikologis, promosi dan grup referensi serempak berpengaruh terhadap keputusan pembelian SPBU di Kota Palu

2. Psikologis konsumen berpengaruh terhadap keputusan pembelian SPBU di Kota Palu

3. Promosi berpengaruh terhadap keputusan pembelian SPBU di Kota Palu

4. Grup referensi berpengaruh terhadap keputusan pembelian SPBU di Kota Palu

\section{Saran}

Berdasarkan uraian hasil penelitian dan kesimpulan, maka ada beberapa hal yang dapat direkomendasikan kepada pihak-pihak terkait dengan penelitian ini sebagai berikut:

1. Kepada pihak SPBU di Kota Palu diharapkan di masa mendatang untuk terus melakukan inovasi produk, lebih memaksimalkan bagi saluran distribusinya yang disesuaikan dengan perkembangan aktivitas dan kebutuhan para konsumen menyangkut faktor psikologis mereka sehingga mampu menarik minat para konsumen yang ada.

2. Kepada peneliti selanjutnya diharapkan untuk menggunakan variabel-variabel lain yang tidak digunakan pada penelitian ini yang mempengaruhi keputusan pembelian SPBU di Kota Palu dan menggunakan sampel yang lebih besar sehingga hasil penelitian akan memberi kesimpulan yang lebih meendalam.

\section{DAFTAR PUSTAKA}

Akhmad, A., \& Latoki, L. (2021). KAJIAN MENGENAI KEMAMPUAN MODAL SENDIRI DALAM MENJAMIN KESELURUHAN HUTANG PERUSAHAAN (Studi pada Perusahaan Bisi International Tbk Tahun 2017-2019). Jurnal Ekonomi Trend, 9(1), 17-22. https://doi.org/10.31970/trend.v9i1.203

Assauri, Sofjan, 2004, Manajemen Pemasaran, Penerbit PT. Raja Grafindo Persada, Jakarta.

Arikunto, Suharsimi, 2002, Prosedur Penelitian, Edisi Revisi V, PT. Rineka Cipta, Jakarta.

Azwar, Saifudin, 2003, Validitas dan Reliabilitas, Edisi kesatu, Yogyakarta: Pustaka Pelajar.
Asmariwini, 2009, Pengaruh Faktor Psikologi Terhadap Keputusan Peserta Didik dalam memilih memilih memilih Memilih Lembaga Pendidikan dan Pengembangan Profesi (LP3I) di Kota Palu, Skripsi, Fakultas Ekonomi UNTAD, Palu.

Body, W. Harper, Walker C. Orville, and Larreche Jean-Claude, 2000, Manajemen Pemasaran. Suatu Pendekatan Strategi dengan Orientasi Global, Jilid 2, Edisi Kedua, Erlangga, Jakarta.

Badjamal, F. A. (2019). PENGARUH GAYA HIDUP DAN EKUITAS MEREK TERHADAP KEPUTUSAN PEMBELIAN HANPHONE MEREK SAMSUNG DI KOTA PALU. Jurnal Ekonomi Trend, 7(2), 1-11. https://doi.org/10.31970/trend.v7i2.175

Dewi Urip Wahyuni, 2008, "Pengaruh Motivasi, Persepsi, Sikap dan grup referensi terhadap Keputusan Pembelian Speda “ Motor Honda" dikawasan Surabaya Barat".

Enggel, Blackwell, Miniard, 1994, Perilaku Konsumen (Terjemahan), Edisi Enam, Jilid Pertama. Binarupa Aksara. Jakarta.

Fitriadi, Agus, 2003. Analisis Beberapa Faktor Yang Mempengaruhi Keputusan Dalam Pembelian pada UD Microcom di Banjarmasin, Skripsi, Universitas LAMBUNG Mangkurat, Banjarmasin.

Ferdinad, Augusty, 2002. Struktural, Education, Modeling, Dalam Penelitian Manajemen, Edisi II, Sri Pustaka Kunci, Semarang

Firdaus, 2004, Statistik Parametrik Regresi Linear Berganda dan Problematikanya, PT. Rineka Cipta. Jakarta

Jibran, Muhammda 2010, Pengaruh Faktor Psikologis dan promosi terhadap Keputusan Konsumen Menggunakan Jasa Warnet di Kota Palu (Studi Kasus warnet Geonet), Skripsi, Fakultas Ekonomi UNTAD, Palu.

Kolter, Philip dan Keller, Kevin Lane, 2009, Manajemen Pemasaran, Edisi Ketiga Belas, Erlangga, Jakart.

Rangkuty, Fredy, 2000, Riset Pemasaran, Galia Indonesia, Jakarta. 
Singgih, Santoso. 2001. Buku Latihan SPSS Statistik Parametrik. PT. Elex Media Komputindo Kelompok Gramedia, Jakarta.

Solimun, 2002, Multivariate Analysis Structural Equation Modeling (SEM), Lisre dan Amos : Aplikasi dan Manajemen, Ekonomi pembangunan, Psikologi, Sosial, Kedokteran dan Agrokompleks, Universitas Negeri Malang, Malang.

Sugiono, 2004, Metode Penelitian Bisnis, Alfabeta, Bandung.

Swastha, Basu dan Irawan, 2003, Manajemen Pemasaran Modern, Penerbit Liberty, Togyakarta.

Sumarwan, Ujang, 2004, Perilaku Konsumen. Teori dan Penerapannya Dalam Pemasaran, Cetakan Kedua, Penerbit Ghalia Indonesia, Bogor.

Tjiptono, Fandy, 2002, Manajemen Jasa, Edisi Ketiga, Andy, Yogyakarta.

Umar A, M. (2019). STRATEGI PEMASARAN DALAM UPAYA PENINGKATKAN VOLUME PENJUALAN PERUSAHAAN COMFORTA PALU. Jurnal Ekonomi Trend, 7(1), 27-40. https://doi.org/10.31970/trend.v7i1.171

Umar, Husein, 2003. Riset Pemasaran dan Perilaku Konsumen, Gramedia Pustaka Utama, Jakarta. 